\title{
Dominant carrier market power in United States international telephone markets
}

\author{
James Alleman \\ University of Colorado at Boulder \\ Gary Madden, Scott J. Savage \\ Curtin University of Technology
}

\begin{abstract}
An econometric model is used to examine market power in US international telephone markets. Lerner index estimates suggest AT\&T's collection rate-cost margin was between 12 and 24 percent during 1991 to 1995 . These relatively low margins support the FCC's 1996 decision to lift dominant firm regulation from AT\&T. Although Lerner estimates imply deadweight welfare losses of up to \$261 million per annum, such losses are small compared to those from the inefficient pricing of international interconnection. Settlement rate-cost margins on US bilateral markets of approximately 89 percent translate into a $\$ 4,907$ million transfer from consumers to carriers in 1995 .
\end{abstract}

October 1999

Key words: collection rates, dominant firm, market power, settlement rates

JEL Classification: L10, L13, L96

We would like to thank Yongmin Chen, George Ford, Doug Galbi, Ken Stanley, Lester Taylor, Mark Uretsky, Michael Ward and seminar participants at the $27^{\text {th }}$ Telecommunications Policy Research Conference, Alexandria, the 1999 International Communications Forecasting Conference, Denver, the FCC and the University of Colorado at Boulder, for comments and suggestions. Curtin Business School financial support to assist Alleman's 1998 Visiting Fellowship at the Communications Economics Research Program (CERP), Curtin University of Technology, is acknowledged. Corresponding author: Scott Savage, CERP, Department of Economics, Curtin University of Technology, GPO Box U1987, Perth, Western Australia 6845, Tel: +61-8-9266-7051, fax: +61-8-9266-3026, e-mail: savages@ cbs.curtin.edu.au. 


\section{Introduction}

Prior to the divestiture of AT\&T there were concerns that Regional Bell Operating Companies (RBOCs) would distort competition in long-distance markets through crosssubsidisation, and the incumbent would exert market power by providing rivals with inferior access to bottleneck facilities (Brennan 1987, Hausman 1995, Ward 1995). Accordingly, the Modification of Final Judgement prevented the newly divested RBOCs from providing international message telephone services (IMTS) and inter-LATA services. The FCC also adopted a system of regulation which classified carriers "dominant" according to their ability to exercise market power. Dominant firms were subject to additional regulation intended to prevent anti-competitive behaviour. For instance, AT\&T operated under rate-of-return regulation until 1989, and price-cap regulation for three telecommunications service baskets thereafter. ${ }^{1}$ Additional regulation and oversight was also imposed on US carriers negotiating operating agreements with foreign monopolies, and US carriers affiliated with foreign carriers (Brands and Leo 1999).

By 1995 new entrants MCI and Sprint had obtained accounting rate agreements for all major markets, and shared ownership of international facilities with AT\&T (FCC 1997a). ${ }^{2}$ More importantly, several long-distance networks were developed within the US to compete with AT\&T for connection with international facilities. In 1993 the FCC concluded there was sufficient competition in service basket's (ii) and (iii) to relax rateregulation, and in 1996, AT\&T was declared non-dominant in the provision of IMTS. The decision to reclassify AT\&T was primarily based on evidence concerning entry barriers. 
In particular, the FCC (1996; II6) argued that "domestic competition prevents AT\&T from leveraging control over its domestic network to shut out competition on the international segment. In short, it is no longer plausible to view AT\&T as controlling bottleneck facilities".

Given that AT\&T held over 50 percent of the IMTS market during 1995, the FCC's (1996) decision to reclassify AT\&T non-dominant was somewhat controversial. This study examines competition and the extent of market power in US IMTS markets within the framework of the dominant firm-competitive fringe (DF-CF) pricing model. Econometric methods are used to estimate structural parameters which confer market power, namely, the competitive fringe's supply elasticity and the dominant carrier's residual demand elasticity. Calculation of a Lerner index from these elasticities provides an estimate of the percentage retail price (collection rate) markup over marginal cost for AT\&T. Lerner index estimates are used to assess the FCC's decision, calculate potential welfare losses from pricing collection rates above cost, and examine the potential for market entry by RBOCs. ${ }^{3}$ The pricing of settlement rates is also investigated.

The paper is organised as follows. US industry structure and price formation are discussed in Section 2. This discussion provides empirical evidence to support the use of the DF-CF model. A model for estimating market power is outlined in Section 3. The model is estimated in Section 4, whilst market power, welfare implications and settlement rate pricing are discussed in Section 5. Section 6 contains concluding remarks. 


\section{Industry structure and price formation}

The DF-CF pricing model assumes the market for a homogenous service is comprised of a dominant price leader (AT\&T) and a fringe of quasi-competitive carriers. ${ }^{4}$ When the nondominant carrier's market share is small relative to market demand it views own output as having no affect on price. These rival carriers form a competitive fringe and equate marginal cost with the price set by AT\&T.

The assumption that AT\&T held a dominant market share from 1991 to 1995, and faced a group of relatively small carriers, is supported by FCC (1997a) data. In 1991, AT\&T's market share (in minutes) was 72.7 percent, whilst MCI and Sprint held 16.5 and 6.9 percent of the market, respectively. Although AT\&T's market share declined from 1991 to 1995 , it maintained dominance. At 1995, AT\&T had 62 percent of the market, MCI 26.8 percent, and Sprint 8.2 percent. Smaller carriers and over 200 resellers supplied the remaining minutes. Such changes in market share are consistent with the DF-CF model when absolute market growth exceeds that of fringe carriers. Between 1991 and 1995 total US IMTS traffic increased by 6.99 billion minutes, whilst fringe output increased by 4.75 billion minutes.

Anecdotal evidence suggests IMTS pricing has characteristics consistent with AT\&T acting as a price leader to MCI and Sprint. Listed collection rates for AT\&T, MCI and Sprint are generally similar across all rate classifications. ${ }^{5}$ Whilst data limitations prevent the analysis of carrier specific IMTS price formation, supportive anecdotal evidence can be 
inferred from domestic long-distance markets. Kahai et al (1996) provide econometric evidence which supports DF-CF pricing in the inter-state market from 1984 to 1993. Hausman (1995) suggests IXC competition, especially for residential and small business customers, has become a situation where AT\&T sets prices (subject to price-caps) followed by its main rivals. For instance, following AT\&Ts price increases in 1993 and 1994 both MCI and Sprint could have held prices constant and captured market share from AT\&T. Instead they chose to increase their prices along with AT\&T (Hausman 1995).

The DF-CF model assumes the services offered by the incumbent and new entrants are not differentiated. Service differentiation in long-distance markets arises at the originating point of the circuit when non-AT\&T subscribers are required to dial additional digits to place a call (“non-premium access"). To allow new entrants to provide services comparable to those of AT\&T, RBOCs are obliged to install switching equipment that allows for "equal access" (1+ dialing) by all long-distance carriers. At 1995, almost 99 percent of telephone lines had been converted to equal access, and non-premium access differentiation between AT\&T and fringe carriers has been largely eliminated. Nevertheless, to account for any perceived differentiation by subscribers, an equal access argument is included in the fringe supply equation below.

The evidence above suggests that the DF-CF model is a reasonable approximation of US IMTS markets for the period 1991 through $1995 .^{6}$ The opportunity to apply this model diminishes substantially after 1995 with industry evolution toward a less regulated, competitive structure. Since 1995, service provider market share has grown dramatically, 
whilst increased carriage of data traffic has the potential to affect industry structure and competitive behaviour. Finally, the 1996 Telecommunications Act allows RBOC subsidiaries to enter IMTS markets provided they satisfy competitive requirements under Section 214 and Section 271 of the Communications Act 1934. At 1997 the FCC had authorised the provision of out-of-region (non-local) switched resale and facilities-based services for five RBOCs.

\section{Empirical model}

The negative inverse of AT\&T's residual demand elasticity $\left(\varepsilon^{\mathrm{d}}\right)$ provides an estimate of the degree of market power held by the dominant carrier:

$$
L=\left(P_{O}-M C_{O}{ }^{d}\right) / P_{O}=-1 / \varepsilon^{d}
$$

where $\mathrm{L}$ is the Lerner index of market power, $\mathrm{P}_{\mathrm{O}}$ is the collection rate for an outgoing call from the US to a foreign country, and $\mathrm{MC}_{\mathrm{O}}{ }^{\mathrm{d}}$ is AT\&T's marginal cost of providing outgoing IMTS. ${ }^{7}$ Following Saving (1970) (1) is rewritten as:

$$
\mathrm{L}=1 /\left[\left(\varepsilon+\left(1-\mathrm{MS}^{\mathrm{d}}\right) \eta\right) / \mathrm{MS}^{\mathrm{d}}\right]
$$

where $\varepsilon$ is the market demand elasticity with respect to the collection rate, MS ${ }^{\mathrm{d}}$ is AT\&T's market share and $\eta$ is the fringe's own-price supply elasticity. ${ }^{8}$ To calculate $L, M^{d}$ is obtained from FCC data, whilst $\varepsilon$ and $\eta$ need to be empirically estimated. 
Consider a bilateral market for international outgoing calls from the US to a foreign country. Given the ISP that all carriers must accept the same settlement rate, the inverse supply equation for the competitive fringe in bilateral market $i=1, \ldots, n$, at time $t=1$, ..., $T$ is:

$$
P_{\text {Oit }}=\alpha_{0 i}+\alpha_{1} Q_{O}^{f}{ }_{\text {it }}+\alpha_{2} P_{\text {Sit }}+\alpha_{3} P_{\text {At }}+\alpha_{4} d_{t}+\alpha_{5} Q_{\text {Ot }}+\alpha_{6} Q_{S}+\alpha_{7} T_{t}+e_{i t}
$$

where $\mathrm{Q}_{\mathrm{O}}{ }^{\mathrm{f}}$ is outgoing IMTS calls from US fringe carriers to the foreign country, $\mathrm{P}_{\mathrm{S}}$ is the settlement rate for a call between the US and $\mathrm{f}$ (the fringe carrier's payment to access foreign country networks), $\mathrm{P}_{\mathrm{A}}$ is the local-exchange access charge, $\mathrm{df}$ is the extent of product differentiation between AT\&T and fringe carriers, QS are network quality of service indicators at the US and foreign ends of the market, respectively, $\mathrm{T}$ is technological advance and $\mathrm{e}$ is an additive disturbance term. ${ }^{9}$

The point-to-point demand functions of Larson et al (1990) allow calls in one direction to affect return calls through reversion and reciprocity. US outgoing market demand is:

$$
\mathrm{Q}_{\mathrm{Oit}}=\beta_{0 \mathrm{i}}+\beta_{1} \mathrm{P}_{\mathrm{Oit}}+\beta_{2} \mathrm{Y}_{\mathrm{Ot}}+\beta_{3} \mathrm{Q}_{\mathrm{Iit}}+\beta_{4} \mathrm{Com}_{\mathrm{it}}+\beta_{5} \mathrm{QS}_{\mathrm{Ot}}+\mathrm{u}_{\mathrm{it}}
$$

where $Q_{O}$ is total outgoing IMTS calls from the US to the foreign country, $\mathrm{Y}_{\mathrm{O}}$ is US income, $\mathrm{Q}_{\mathrm{I}}$ is total incoming IMTS calls from the foreign country, Com is the calling community of interest and $\mathrm{u}$ is an additive disturbance term. 
To enable consistent estimation of (4) and (5) the endogeneity of price and quantity must be recognised. Accordingly, a market demand equation for incoming calls from the foreign country to the US (6) is specified, and (4) through (6) are estimated as a system:

$$
\mathrm{Q}_{\text {Iit }}=\gamma_{0 \mathrm{i}}+\gamma_{1} \mathrm{P}_{\mathrm{Iit}}+\gamma_{2} \mathrm{Y}_{\mathrm{Iit}}+\gamma_{3} \mathrm{Q}_{\mathrm{Oit}}+\gamma_{4} \mathrm{Com}_{\mathrm{it}}+\gamma_{5} \mathrm{Acomp}_{\mathrm{it}}+\mathrm{v}_{\mathrm{it}}
$$

where $\mathrm{P}_{\mathrm{I}}$ is the collection rate for an incoming call from the foreign country to the US, $\mathrm{Y}_{\mathrm{I}}$ is foreign country income, Acomp is asymmetric competition and $\mathrm{v}$ is an additive disturbance term.

Econometric estimation is on annual data for 30 bilateral markets from 1991 to 1995. Sampled countries are Argentina, Australia, Austria, Belgium, Canada, Chile, Colombia, Costa Rica, Denmark, Ecuador, Egypt, France, Greece, Honduras, India, Ireland, Israel, Italy, Japan, Korea (South), Mexico, Netherlands, Philippines, Portugal, Singapore, Spain, Sweden, Switzerland, Turkey, and the UK. These bilateral markets represent approximately 54 percent of total 1995 outgoing traffic, and 65 percent of incoming traffic. Definitions, sample means and standard deviations for all variables are provided in Table 1.

Table 1 Variable description and sample statistics 1991-1995

The a priori signs of the arguments included in (4) through (6) require some discussion. The DF-CF model suggests $\partial \mathrm{P}_{\mathrm{O}} / \partial \mathrm{Q}_{\mathrm{o}}{ }^{\mathrm{f}} \geq 0$ or fringe carrier willingness to increase supply in 
response to AT\&T collection rate increases. As $\partial \mathrm{P}_{\mathrm{O}} / \partial \mathrm{Q}_{\mathrm{O}}{ }^{\mathrm{f}}$ tends to zero, fringe supply becomes more elastic, reflecting greater potential competition. Carrier access to international and domestic networks is a primary production input, and lower settlements and access charges should shift fringe supply outward implying $\partial \mathrm{P}_{\mathrm{O}} / \partial \mathrm{P}_{\mathrm{S}} \geq 0$ and $\partial \mathrm{P}_{\mathrm{O}} / \partial \mathrm{P}_{\mathrm{A}} \geq$ 0. Kahai et al (1996) find growth in equal access reduces differentiation between AT\&T and fringe carriers. This enhances the fringe carrier's ability to expand output and places pricing pressure on the dominant firm. As such, increased equal access is expected to shift fringe supply outward suggesting $\partial \mathrm{P}_{\mathrm{O}} / \partial \mathrm{df} \leq 0$. QS and $\mathrm{T}$ account for exogenous shifts in supply from network enhancement and technology change, respectively. Improved network quality through greater US digitisation suggests higher collection rates, however, digitisation may lead to lower collection rates through increased network efficiency. Accordingly, the sign of $\partial \mathrm{P}_{\mathrm{O}} / \partial \mathrm{QS}_{\mathrm{O}}$ is indeterminate. Improved foreign network quality (and access) may induce fringe carriers to expand output and shift fringe supply outward suggesting $\partial \mathrm{P}_{\mathrm{O}} / \partial \mathrm{QS} \mathrm{S}_{\mathrm{I}} \leq 0$. Technological advance is measured by a time trend $(\mathrm{T})$ and an outward shift in fringe supply due to technology change implies $\partial \mathrm{P}_{\mathrm{O}} / \partial \mathrm{T} \leq 0$.

Theory predicts $\partial \mathrm{Q}_{\mathrm{O}} / \partial \mathrm{P}_{\mathrm{O}} \leq 0, \partial \mathrm{Q}_{\mathrm{I}} / \partial \mathrm{P}_{\mathrm{I}} \leq 0$ and $\partial \mathrm{Q} / \partial \mathrm{Y}>0$. There are no a priori assumptions made about the relationship between outgoing and incoming traffic. Call reversion suggests outgoing and incoming call volumes are substitutes, $\partial \mathrm{Q}_{\mathrm{O}} / \partial \mathrm{Q}_{\mathrm{I}}<0$, whilst reciprocity implies outgoing and incoming calls are complimentary, $\partial \mathrm{Q}_{\mathrm{O}} / \partial \mathrm{Q}_{\mathrm{I}}>0$. Network externalities are allowed for through the inclusion of Com in demand equations. Com is proxied by potential international connections (market size). The greater the size 
of the market the more potential for calls, so $\partial \mathrm{Q} / \partial \mathrm{Com}_{1} \geq 0$ is expected to hold (Larson et al 1990). ${ }^{10}$ In a quasi-competitive IMTS market such as the US, improved network quality can shift the demand curve outward implying $\partial \mathrm{Q}_{\mathrm{O}} / \partial \mathrm{SQ}_{\mathrm{O}} \geq 0$. Acomp captures incoming demand shifts due to asymmetric competition. Because US carriers mostly operate in asymmetrically competitive markets, collection rate reductions in the US have increased outgoing traffic relative to incoming traffic from "high price" countries. This occurs directly as US consumers respond to declining collection rates, and indirectly, as a result of substitution between the higher-price incoming and lower-price outgoing traffic. ${ }^{11}$ The derivative $\partial \mathrm{Q}_{\mathrm{I}} / \partial$ Acomp $<0$ suggests relatively lower incoming traffic from foreign monopoly countries.

\section{Model estimation}

The system (4) through (6) is estimated by 2SLS, with appropriate corrections for firstorder autocorrelation and heteroskedasticity. Natural logs are taken for all variables except the time trend and network quality indices. Estimating equations contain dummy variables to allow different intercepts for each bilateral market. Given that the US-Canada and USMexico bilateral markets are contiguous, and so may closely resemble inter-state markets, model stability is assessed by estimating the system for subsamples excluding Canada and Mexico. Model estimates are reported in Table 2 through Table 4.

\section{Table 2 2SLS estimates for fringe inverse supply relation (4)}




\section{Table 3 2SLS estimates for outgoing demand equation (5)}

\section{Table 4 2SLS estimates for incoming demand equation (6)}

The positive sign for $\mathrm{Q}_{\mathrm{o}}{ }^{\mathrm{f}}$ is consistent with an upward sloping fringe supply curve within the DF-CF model. The negative sign for df supports the Kahai et al (1994) conjecture that increased equal access, along with commensurate decreases in product differentiation, increases fringe supply. Surprisingly, both access charges are insignificant for the full sample and the subsample excluding Canada. Relatively strong correlations between $\mathrm{P}_{\mathrm{S}}$, $\mathrm{P}_{\mathrm{A}}$ and $\mathrm{T}$ over the sample period could be masking the relationship between access charges and fringe supply. A positive relationship between settlement rates and collection rates becomes apparent when Mexico is excluded from the sample. ${ }^{12}$ Whilst Kahai et al (1996) show that fringe supply shifts backwards in interstate long-distance markets with increased local access charges, this affect is not observed in international markets. A possible explanation for this finding is that local access charges are not the principal production input in international telephone service production. Table 1 shows that local access charges comprise about five percent of the US outgoing collection rate.

The estimated outgoing call demand equation (5) shows all coefficients are significant and signed according to expectations. The coefficient for $\mathrm{P}_{\mathrm{O}}$ implies a downward sloping US

outgoing demand curve, whilst outgoing IMTS demand is elastic with respect to $\mathrm{Y}_{\mathrm{O}}{ }^{13}$ The significance of $\mathrm{Q}_{\mathrm{I}}$ suggests incoming traffic influences outgoing traffic, independent of price and income effects. Given this study's focus on price elasticities, no attempt is made 
to isolate the reverse-traffic coefficient into separate reversion, call and network externality effects. Community of interest (proxied by potential network connections) is positively related to outgoing demand, as is US network quality. Income, reverse-traffic and community of interest variables assist in the explanation of incoming demand (5). Acomp captures shifts in the demand curve due to the asymmetrically competitive nature of US bilateral markets. For calls terminating in the US, demand appears to be lower in markets served by a foreign monopoly.

\section{Market power, settlement rate pricing and welfare}

Estimation of point-to-point demand equations permit the calculation of flow-through elasticities, which reflect price changes and feedback through the reverse-traffic variable. Table 5 presents flow-through price elasticities for US outgoing call demand, obtained by substituting (6) into (5). The range of uni-directional estimates for $\varepsilon[-0.932,-0.677]$ are consistent with those provided by Taylor (1994) for longer haul inter-LATA markets $[-0.75,-0.50] .{ }^{14}$ The estimated fringe supply elasticities $\left(\eta=1 / \alpha_{1}\right)$ range from 5.435 to 12.35, and are within the bounds provided for interstate long-distance by Kahai et al (1996) and Ward (1995). Table 5 also reports values of AT\&T's residual demand elasticity and Lerner index from substitution of $\varepsilon, \eta$ and $\mathrm{MS}^{\mathrm{d}}$ into (2). The range of values for AT\&T's residual demand elasticity $[-8.403,-4.166]$ imply Lerner index estimates between 0.119 and 0.24. These estimates closely correspond to those provided by Kahai et al (1996), 0.13 to 0.29, and are below those cited for many other US industries. Hall's (1988) study of 26 industries produces an average market power estimate of 0.62, whilst Bresnahan's (1989) 
survey of 12 industries yields an average market power estimate of 0.30 . Given their proximity to zero, Lerner estimates reported here suggest that AT\&T did not hold substantial market power in the pricing of collection rates for the period 1991 to 1995.

\section{Table 5 AT\&T's residual demand elasticity and Lerner index}

Despite the relatively low values for AT\&T's Lerner index, the implied price-cost margins of 12 to 24 percent suggest welfare losses. Following Ward (1995), the ratio of potential deadweight loss to industry revenue is calculated by $\left[\left(1-(1-L)^{1+\varepsilon}\right) /(1+\varepsilon)\right]-L^{15}$ Assuming, $\varepsilon=[-0.932,-0.677]$ and $\mathrm{L}=[0.119,0.24]$ the ratio of potential deadweight loss to industry revenue ranges from 0.0072 to 0.0223 . Multiplying these ratios by average industry billed revenue of $\$ 11.53$ billion per annum between 1991 and 1995 suggests welfare losses of between $\$ 82$ and $\$ 261$ million per annum from supra-competitive pricing. RBOCs, with their existing subscriber base, extensive fibre optic networks, technical, and marketing expertise, are well placed to capture some of these rents.

Finally, the study of market power in US IMTS markets is not complete without discussion of the inefficiencies within the international accounting rate system. Accounting rates are mutually determined in bilateral negotiations between US and foreign carriers. ISPs ensure that settlement rates are typically one-half of the accounting rate. Although inefficient, this arrangement worked well for the monopolies when the carriers provided services, and costs and demand were similar across countries. However, recent technology change and market liberalisation has seen asymmetric cost and demand conditions prevail on many US 
bilateral markets. Under these conditions, the high cost (low demand) foreign monopoly country has greater bargaining power during negotiations as it has less to lose when an accounting rate agreement is not reached. ${ }^{16}$ As such, settlement rates have typically remained high relative to falling costs. ${ }^{17}$ A comparison of the FCC's (1997b) estimate of the long-run incremental per-minute cost of terminating international calls [ $\$ 0.06, \$ 0.09$ ] with the average 1995 settlement rate of $\$ 0.56$ implies settlement rate-cost margins of between 84 and 89 percent. With 1995 outgoing traffic totaling 10.58 billion minutes, such margins suggest rents in settlement rate pricing of up to $\$ 4,907$ million during 1995 . Given this substantial sum, non-US carriers have an incentive to cooperate strategically, both within and across countries, to maintain this surplus.

Rent seeking behaviour within the international settlement rate system has combined with several de facto regulations to maintain downward rigidity on settlement rates and collection rates. ISPs protect the incumbent's market power as new entrants are unable to exploit their (newer) technology induced cost advantage by negotiating a lower settlement rate. Proportionate return entitles carriers generating outgoing calls to receive a return proportion of incoming calls, and to make profits from the excess of the settlement rate over the cost of terminating incoming calls. For instance, Johnson (1991) shows the average per-minute collection rate for US calls to Brazil was $\$ 1.17$ in 1986 , while the corresponding settlement payment was $\$ 1.25$ per-minute. Although US carriers lost revenue of $\$ 1.6$ million for setting the collection rate below the settlement rate, the lower collection rate increased outgoing traffic which, in turn, stimulated additional incoming traffic through reciprocity. Consequently, the loss in domestic collection revenue was 
more than compensated for by the $\$ 33.6$ million settlement revenue earned for terminating incoming calls from Brazil. Scanlan (1998) suggests that US facilities-based carriers may use proportionate return to avoid direct price competition for outgoing minutes because of the high sunk costs of installing facilities. The strategy is to supply outgoing minutes which have been purchased in a foreign country through a call-back or calling-card service. These re-originated minutes allow carriers to indirectly increase their share of outgoing traffic, which entitles the carrier to receive a return proportion of incoming calls and settlement rate revenue.

\section{Conclusions}

The extent of market power in US IMTS markets is examined through the DF-CF pricing model. Estimation of the fringe's own-price supply elasticity and AT\&T's price elasticity of (outgoing) residual demand allows several inferences to be made about competitive behavior. The supply elasticity estimates indicate a substantial increase in fringe carrier supply in response to an AT\&T-initiated price change. This finding by itself is consistent with FCC (1996) arguments of significantly reduced barriers to expansion (and entry) through the removal of control of bottleneck facilities. Lerner index estimates, calculated from AT\&T's residual demand elasticity, provide a measure of the percentage collection rate markup over marginal cost for AT\&T. Estimates reported here imply a Lerner index of between 0.119 and 0.240 . 
Our results confirm that AT\&T did not hold substantial market power in collection rate pricing from 1991 to 1995 . These results are consistent with observed data and support the FCC's (1996) decision to reclassify AT\&T non-dominant. Lerner estimates are also expected to be slightly lower when rate regulation prevents AT\&T from setting (residual) marginal revenue to marginal cost at a higher profit-maximising collection rate. Further, US policies which promote competitive price formation in international IMTS provision should be most effective at the US end of bilateral markets. An advantage of this study is that the Lerner index estimates obtained can be used to calculate deadweight welfare losses. Losses of up to $\$ 261$ million per annum from US collection rate pricing above marginal cost are inferred. Whilst substantial in their own right, these losses are small compared to the rents available to carriers from inefficient settlement rate pricing, potentially $\$ 4907$ million in 1995.

The ability of US carriers to affect substantial IMTS price reductions is limited unless competitive reforms are reciprocated by foreign governments. Asymmetric cost and market structure conditions lead to situations whereby AT\&T prices IMTS to reduce collection rate-cost margins, but will agree to excessive settlement rate-cost margins to ensure operating agreements are reached with foreign carriers. Potential new facilitiesbased entrants, such as the RBOCs, are likely to exhibit similar pricing behaviour unless they arrange interconnection through international private lines which are not subjected to settlement rates and proportionate return. Clearly, a major task for US authorities, and other liberalsing countries, is reform of the accounting rate system. Removal of foreign 
carrier monopoly power and efficient settlement rate pricing will provide consumers with substantially lower prices and reduce the flow of rents from consumers to carriers.

\section{References}

Acton, Jan Paul, and Vogelsang, Ingo (1992), "Telephone Demand Over the Atlantic: Evidence from Country-Pair Data”, Journal of Industrial Economics, 40, 1-19.

Alleman, James (1998) "International Settlements: An Analysis of Rates," Communications \& Strategies, Special Edition, DATE, Montpellier, France $2^{\text {nd }}$. Quarter. Brands, Henk and Leo, Evan (1999), The Law and Regulation of Telecommunications Carriers, Boston: Artech House.

Brennan, T. (1987), "Why Regulated Firms Should Be Kept Out of Unregulated Markets: Understanding the Divestiture in U.S. v. AT\&T”, Antitrust Bulletin, 32, 741-793.

Bresnahan, Timothy (1989), "Empirical Studies of Industries with Market Power", in Schmalensee, Richard, and Willig, Robert (eds.), Handbook of Industrial Organization Volume II, Amsterdam: Elsevier Science Publishers.

Cave, Martin, and Donnelly, Mark (1996), “The Pricing of International Telecommunications Services by Monopoly Operators", Information Economics and Policy, 8, 107-123.

FCC (1997a), Trends in the US International Telecommunications Industry, Common Carrier Bureau, Washington: FCC.

FCC (1997b), Benchmarks Order IB Docket No. 96-261, Washington: FCC.

FCC (1997c), Trends in Telephone Service, Common Carrier Bureau, Washington: FCC. 
FCC (1996), Motion of AT\&T Corp. to Be Declared Non-Dominant for International Service, Order 11 FCC Rcd 17,963, Washington: FCC.

FCC (1992), Calling Prices for International Message Telephone Service Between the United States and Other Countries, Common Carrier Bureau, Washington: FCC.

FCC (1991-95), Statistics of Communications Common Carriers (various issues), Washington: FCC.

Ford George S., (1999) 'Flow-Through and Competition in the International Message Telephone Service Market', www.ec-group.net/download.htm.

Ford George S., and Jackson, John D., (1999) 'Demand Elasticities for International Message Telephone Service', www.ec-group.net/download.htm.

Garin Munoz, Teresa, and Perez Amaral, Teodosia (1996), "Demand for International Telephone Traffic in Spain: An Econometric Study Using Provincial Panel Data", Information Economics and Policy, 8, 289-315.

Hackl, Peter, and Westlund, Anders (1995), "On Price Elasticities of International Telecommunications Demand", Information Economics and Policy, 7, 27-36.

Hall, Robert, (1988), "The Relation Between Price and Marginal Cost in US Industry", Journal of Political Economy, 83, 807-827.

Hausman, Jerry (1995), “Competition in Long-Distance and Telecommunications Equipment Markets: Effects of the MFJ", Managerial and Decision Economics, 16, 365-383.

ITU (1996a), Direction of Traffic: Trends in International Telephone Tariffs, Second Edition, Geneva: ITU.

ITU (1996b), World Telecommunications Indicators Database, Geneva: ITU. 
Johnson, Leland, (1991), "Dealing with Monopoly in International Telephone Service: A US Perspective", Information Economics and Policy, 4, 225-247.

Kahai, Simran, Kaserman, David, and Mayo, John (1996), "Is the 'Dominant Firm' Dominant? An Empirical Analysis of AT\&T's Market Power", Journal of Law and Economics, 39, 499-517.

Larson, Alexander, Lehman, Dale, and Weisman, Dennis (1990), “A General Theory of Point-to-Point Long Distance Demand”, in De Fontenay, Alain, Shugard, Mary, and Sibley, David (eds.), Telecommunications Demand Modelling, Amsterdam: NorthHolland.

Madden, Gary, and Savage, Scott, "Market Structure, Competition and Pricing in United States International Telephone Services Markets", Review of Economics and Statistics, forthcoming.

Mitchell, Bridger, and Vogelsang, Ingo (1991), Telecommunications Pricing: Theory and Practice, Cambridge: Harvard University Press.

Saving, Thomas, (1970), "Concentration Ratios and the Degree of Monopoly", International Economic Review, 11, 139-146.

Scanlan, Mark, (1998), "Using Call-back to Demonstrate the Discriminatory Nature of the Proportionate Return Rule”, Telecommunications Policy, 11, 913-930.

Scherer, F., and Ross, David (1990), Industrial Market Structure and Economic Performance, Third Edition, Boston: Houghton Mifflin Company.

Taylor, Lester (1994), Telecommunications Demand in Theory and Practice, Boston: Kluwer Academic Publishers. 
Ward, M. (1995), "Measurements of Market Power in Long Distance Telecommunications”, Staff Report, D.C., Federal Trade Commission, Bureau of Economics.

World Bank (1997), 1997 World Development Indicators, Washington: World Bank.

Wright, Julian (1999), "International Telecommunications, Settlement Rates, and the FCC”, Journal of Regulatory Economics, 15, 267-291. 


\section{TABLE 1}

Variable description and sample statistics 1991-1995

\begin{tabular}{|c|c|c|c|}
\hline Variable & Definition & Mean & Std Dev \\
\hline$\overline{\mathrm{P}_{\mathrm{O}}}$ & real per-minute peak (standard) outgoing collection rate (\$) & 1.12 & 0.26 \\
\hline $\mathrm{P}_{\mathrm{I}}$ & real per-minute peak incoming collection rate $(\$)$ & 0.92 & 0.46 \\
\hline $\mathrm{Q}_{\mathrm{O}}$ & total minutes of outgoing US traffic (millions) & 272 & 513 \\
\hline $\mathrm{Q}_{\mathrm{I}}$ & total minutes of incoming traffic (millions) & 149 & 327 \\
\hline$Q_{O}^{f}$ & $\mathrm{Q}_{\mathrm{O}}$ less ATT's minutes of outgoing traffic (millions) & 104 & 209 \\
\hline $\mathrm{P}_{\mathrm{S}}$ & real per-minute settlement rate for outgoing traffic $(\$)$ & 0.52 & 0.19 \\
\hline $\mathrm{P}_{\mathrm{A}}$ & $\begin{array}{l}\text { real per-minute price US long-distance carriers pay local-exchange carriers } \\
\text { for access to local networks }(\$)\end{array}$ & 0.06 & 0.003 \\
\hline $\mathrm{df}$ & the share of telephone lines converted to equal access & 0.97 & 0.02 \\
\hline $\mathrm{T}$ & time trend & - & - \\
\hline $\mathrm{QS}_{\mathrm{O}}$ & $\begin{array}{l}\text { US network quality index, one plus the percentage of mainlines connected } \\
\text { to digital switches }\end{array}$ & 167 & 12.7 \\
\hline $\mathrm{QS}_{\mathrm{I}}$ & $\begin{array}{l}\text { foreign network quality index, one plus the percentage of mainlines } \\
\text { connected to digital switches }\end{array}$ & 160 & 21.1 \\
\hline $\mathrm{Y}_{\mathrm{O}}$ & US real GDP (\$billion) & 19,880 & 513 \\
\hline $\mathrm{Y}_{\mathrm{I}}$ & foreign country real GDP (\$billion) & 9,814 & 7,864 \\
\hline Com & market size, the product of US and foreign country mainlines (billion) & 13,619 & 18,749 \\
\hline Acomp & $\begin{array}{l}\text { equals one when there is a monopoly facilities-based provider at the } \\
\text { foreign end of the market; zero otherwise. }\end{array}$ & - & - \\
\hline $\mathrm{MS}^{\mathrm{d}}$ & AT\&T's share of bilateral market traffic (in minutes) & 0.64 & 0.08 \\
\hline
\end{tabular}

Note. Base year is 1987.

Source. FCC (1991-95, 1997c), ITU (1996a, 1996b), World Bank (1997). 
TABLE 2

2SLS Estimates for fringe inverse supply relation (4)

\begin{tabular}{|c|c|c|c|c|}
\hline \multirow[b]{2}{*}{$\begin{array}{l}\text { Independent } \\
\text { variables }\end{array}$} & \multicolumn{4}{|c|}{ Estimated coefficients (t-ratio) } \\
\hline & Full sample & $\begin{array}{l}\text { Without } \\
\text { Canada }\end{array}$ & $\begin{array}{l}\text { Without } \\
\text { Mexico }\end{array}$ & $\begin{array}{l}\text { Without } \\
\text { Canada and } \\
\text { Mexico }\end{array}$ \\
\hline \multirow[t]{2}{*}{$\mathrm{QO}^{\mathrm{f}}$} & $0.184^{\mathrm{a}}$ & $0.181^{\mathrm{a}}$ & $0.081^{\mathrm{a}}$ & $0.107^{\mathrm{a}}$ \\
\hline & $(5.362)$ & $(4.725)$ & $(3.451)$ & $(4.029)$ \\
\hline \multirow[t]{2}{*}{$\mathrm{P}_{\mathrm{S}}$} & -0.010 & -0.010 & $0.031^{\mathrm{a}}$ & $0.023^{\mathrm{b}}$ \\
\hline & $(-0.450)$ & $(-0.429)$ & $(2.185)$ & $(1.640)$ \\
\hline \multirow[t]{2}{*}{$\mathrm{P}_{\mathrm{A}}$} & 0.049 & 0.004 & 0.168 & 0.075 \\
\hline & $(0.261)$ & $(0.021)$ & $(0.955)$ & $(0.439)$ \\
\hline \multirow[t]{2}{*}{$\mathrm{df}$} & $-3.385^{\mathrm{a}}$ & $-3.518^{\mathrm{a}}$ & $-3.122^{\mathrm{a}}$ & $-3.474^{\mathrm{a}}$ \\
\hline & $(-6.163)$ & $(-6.302)$ & $(-6.330)$ & $(-6.939)$ \\
\hline \multirow[t]{2}{*}{$\mathrm{QS}_{\mathrm{O}}$} & $0.829^{\mathrm{a}}$ & $0.832^{\mathrm{a}}$ & $0.860^{\mathrm{a}}$ & $0.879^{\mathrm{a}}$ \\
\hline & $(15.26)$ & $(14.68)$ & $(17.00)$ & (16.99) \\
\hline \multirow[t]{2}{*}{$\mathrm{QS}_{\mathrm{I}}$} & $-0.075^{\mathrm{a}}$ & $-0.088^{\mathrm{a}}$ & $0.091^{\mathrm{a}}$ & 0.041 \\
\hline & $(-2.480)$ & $(-2.500)$ & $(2.279)$ & $(0.987)$ \\
\hline \multirow[t]{2}{*}{$\mathrm{T}$} & $-0.047^{\mathrm{a}}$ & $-0.045^{\mathrm{a}}$ & $-0.023^{\mathrm{a}}$ & $-0.028^{\mathrm{a}}$ \\
\hline & $(-3.844)$ & $(-0.406)$ & $(2.912)$ & $(-3.381)$ \\
\hline R-square & 0.91 & 0.90 & 0.94 & 0.95 \\
\hline $\mathrm{nT}$ & 150 & 145 & 145 & 140 \\
\hline
\end{tabular}

Note. (a) denotes significance at the five percent level. (b) denotes significance at the ten five percent level. 
TABLE 3

2SLS Estimates for outgoing demand equation (5)

\begin{tabular}{|c|c|c|c|c|}
\hline \multirow[b]{2}{*}{$\begin{array}{l}\text { Independent } \\
\text { variables }\end{array}$} & \multicolumn{4}{|c|}{ Estimated coefficients (t-ratio) } \\
\hline & Full sample & $\begin{array}{l}\text { Without } \\
\text { Canada }\end{array}$ & $\begin{array}{l}\text { Without } \\
\text { Mexico }\end{array}$ & $\begin{array}{c}\text { Without } \\
\text { Canada and } \\
\text { Mexico }\end{array}$ \\
\hline $\mathrm{P}_{\mathrm{O}}$ & $\begin{array}{l}-0.701^{\mathrm{a}} \\
(-7.554)\end{array}$ & $\begin{array}{l}-0.640^{\mathrm{a}} \\
(-7.092)\end{array}$ & $\begin{array}{l}-0.983^{\mathrm{a}} \\
(-8.254)\end{array}$ & $\begin{array}{l}-0.964^{\mathrm{a}} \\
(-7.901)\end{array}$ \\
\hline $\mathrm{Y}_{\mathrm{O}}$ & $\begin{array}{l}1.780^{\mathrm{a}} \\
(3.906)\end{array}$ & $\begin{array}{l}1.959^{\mathrm{a}} \\
(4.427)\end{array}$ & $\begin{array}{l}1.884^{\mathrm{a}} \\
(4.280)\end{array}$ & $\begin{array}{l}1.789^{\mathrm{a}} \\
(3.941)\end{array}$ \\
\hline $\mathrm{Q}_{\mathrm{I}}$ & $\begin{array}{l}0.149^{\mathrm{a}} \\
(4.287)\end{array}$ & $\begin{array}{l}0.173^{\mathrm{a}} \\
(5.344)\end{array}$ & $\begin{array}{l}-0.171^{\mathrm{a}} \\
(-3.839)\end{array}$ & $\begin{array}{l}-0.151^{\mathrm{a}} \\
(-3.320)\end{array}$ \\
\hline Com & $\begin{array}{l}0.452^{\mathrm{a}} \\
(12.91)\end{array}$ & $\begin{array}{l}0.422^{\mathrm{a}} \\
(13.12)\end{array}$ & $\begin{array}{l}0.630^{\mathrm{a}} \\
(13.89)\end{array}$ & $\begin{array}{l}0.604^{\mathrm{a}} \\
(12.75)\end{array}$ \\
\hline $\mathrm{QS}_{\mathrm{O}}$ & $\begin{array}{l}0.740^{\mathrm{a}} \\
(7.270)\end{array}$ & $\begin{array}{l}0.713^{\mathrm{a}} \\
(7.068)\end{array}$ & $\begin{array}{l}0.938^{\mathrm{a}} \\
(8.002)\end{array}$ & $\begin{array}{c}0.981 \\
(8.041)\end{array}$ \\
\hline R-square & 0.99 & 0.99 & 0.98 & 0.98 \\
\hline nT & 150 & 145 & 145 & 140 \\
\hline
\end{tabular}

Note. (a) denotes significance at the five percent level. (b) denotes significance at the ten five percent level. 


\section{TABLE 4}

2SLS Estimates for incoming demand equation (6)

\begin{tabular}{|c|c|c|c|c|}
\hline \multirow[b]{2}{*}{$\begin{array}{l}\text { Independent } \\
\text { variables }\end{array}$} & \multicolumn{4}{|c|}{ Estimated coefficients (t-ratio) } \\
\hline & Full sample & $\begin{array}{l}\text { Without } \\
\text { Canada }\end{array}$ & $\begin{array}{l}\text { Without } \\
\text { Mexico }\end{array}$ & $\begin{array}{c}\text { Without } \\
\text { Canada and } \\
\text { Mexico }\end{array}$ \\
\hline \multirow[t]{2}{*}{$\mathrm{P}_{\mathrm{I}}$} & -0.047 & -0.040 & -0.052 & $-0.058^{b}$ \\
\hline & $(-1.463)$ & $(-1.549)$ & $(-1.303)$ & $(-1.828)$ \\
\hline \multirow[t]{2}{*}{$\mathrm{Y}_{\mathrm{I}}$} & $0.944^{\mathrm{a}}$ & $0.919^{\mathrm{a}}$ & $1.107^{\mathrm{a}}$ & $1.109^{\mathrm{a}}$ \\
\hline & (10.16) & $(9.701)$ & $(9.953)$ & $(10.08)$ \\
\hline \multirow[t]{2}{*}{ Qo } & $0.302^{\mathrm{a}}$ & $0.315^{\mathrm{a}}$ & $0.321^{\mathrm{a}}$ & $0.313^{\mathrm{a}}$ \\
\hline & $(7.151)$ & (7.794) & $(4.705)$ & $(4.755)$ \\
\hline \multirow[t]{2}{*}{ Com } & $0.121^{\mathrm{a}}$ & $0.114^{\mathrm{b}}$ & 0.045 & 0.036 \\
\hline & (1.997) & $(1.852)$ & $(0.594)$ & $(0.471)$ \\
\hline \multirow[t]{2}{*}{ Acomp } & $-0.072^{\mathrm{a}}$ & $-0.084^{\mathrm{a}}$ & $-0.070^{\mathrm{a}}$ & $-0.078^{\mathrm{a}}$ \\
\hline & $(-2.895)$ & $(-2.355)$ & $(-2.827)$ & $(-2.220)$ \\
\hline R-square & 0.95 & 0.95 & 0.94 & 0.94 \\
\hline $\mathrm{nT}$ & 150 & 145 & 145 & 140 \\
\hline
\end{tabular}

Note. (a) denotes significance at the five percent level. (b) denotes significance at the ten five percent level. 


\section{TABLE 5}

AT\&T's residual demand elasticity and Lerner Index

\begin{tabular}{lcccc}
\hline & $\varepsilon$ & $\eta$ & $\varepsilon^{\mathrm{d}}$ & $\mathrm{L}$ \\
\hline Full sample & -0.734 & 5.435 & -4.204 & 0.238 \\
No Canada & -0.677 & 5.525 & -4.166 & 0.240 \\
No Mexico & -0.932 & 12.35 & -8.403 & 0.119 \\
No Canada and Mexico & -0.920 & 9.346 & -6.695 & 0.149
\end{tabular}

Note. The sample mean $\mathrm{MS}^{\mathrm{d}}=0.64$ closely corresponds to AT\&T's mean share of minutes for all bilateral markets. The uni-directional flow-through elasticity, $\varepsilon=$ $\partial \log \mathrm{Q}_{\mathrm{O}} / \partial \log \mathrm{P}_{\mathrm{O}}=\beta_{1} / 1-\beta_{3} \gamma_{3}$, assumes a collection rate change in the US only. 


\section{Endnotes}

${ }^{1}$ Price-caps cover three service baskets: (i) residential and small business domestic, and international services; (ii) toll free "800" services; and (iii) business services such as WATS, private line and various switched commercial services (Mitchell and Vogelsang 1991).

2 The accounting rate is the basic "unit of account" from which international settlement payments are made. The settlement rate determines the amount carrier's pay to access other country networks and can be thought of as an international interconnection cost. A carrier's net settlement is determined by the difference between incoming and outgoing traffic, multiplied by the settlement rate. The International Settlements Policy (ISP) requires all US carriers to accept the same accounting rate for a particular bilateral market, and that settlement rates are the same for outgoing and incoming calls (50:50 rule). This arrangement removed the incentive for a single competitive US carrier to accept less favourable interconnection conditions as they will apply to all carriers. Proportionate return supports the 50:50 rule by guaranteeing all carriers a share of incoming traffic, according to their outgoing traffic market share.

3 Another approach, typically employed in regulatory proceedings, is to use the flowthrough of unit cost to price to assess the competitiveness of long-distance markets (Ford 1999).

${ }^{4}$ Scherer and Ross (1990) and Kahai et al (1996) suggest a threshold market share threshold of 40 percent is required for the largest firm in a industry to exhibit dominant firm behaviour. 
${ }^{5}$ Listed prices, such as those provided by the FCC $(1992 ; 41-46)$, are not an accurate basis for making reseller price comparisons. Pure resellers route calls through a facilities-based carrier by purchasing bulk capacity at a discount to the listed price.

${ }^{6}$ Use of the DF-CF model is primarily justified by observed market shares during the sample period. It is also possible that a dynamic oligopoly game could generate similar market share and pricing patterns. With the available data it is not possible to estimate a market model suggested by such a game. Nor is it possible to test the relative performance of competing models.

${ }^{7}$ (1) assumes AT\&T set marginal revenue equal to marginal cost. When rate regulation prevents this condition from being met, the observed price may be below the profitmaximising price, implying a lower value for $\mathrm{L}$.

${ }^{8}$ Assuming fringe resale carriers purchase capacity at a discounted wholesale price and resell those minutes at the prevailing retail price set by AT\&T, (1) can also be written as:

$$
\mathrm{L}=1 /\left[\left(\varepsilon+\left(1-\mathrm{MS}^{\mathrm{d}}-\mathrm{MS}^{\mathrm{r}}\right) \eta^{\mathrm{f}}+\left(1-\mathrm{MS}^{\mathrm{d}}-\mathrm{MS}^{\mathrm{f}}\right) \eta^{\mathrm{r}}\right) / \mathrm{MS}^{\mathrm{d}}\right]
$$

where $\mathrm{MS}^{\mathrm{f}}$ is the market share of facilities-based fringe carriers, $\mathrm{MS}^{\mathrm{r}}$ is the market share of resale fringe carriers, $\eta^{\mathrm{f}}$ is the facilities-based fringe carriers own-price supply elasticity, and $\eta^{\mathrm{r}}$ is the resale fringe carriers supply elasticity with respect to the wholesale price. Whilst a lack of resale data prevents the calculation of (3), it can be shown that (2) $=(3)$ when $\eta^{\mathrm{f}}=\eta^{\mathrm{r}}=\eta$ or $\mathrm{MS}^{\mathrm{r}}=0$. Since resellers purchase their primary input (network access) from IXCs it is reasonable to assume the reseller's supply elasticity is similar to that of 
facilities-based carriers. When this is not the case, the relatively low value for $\mathrm{MS}^{\mathrm{r}}$ over the sample period (annual average is eight percent), ensures any bias from calculating $\mathrm{L}$ from (2) will be small.

${ }^{9}$ The settlement rate is an appropriate measure of international access in an inverse-supply equation. In flow-through models, (marginal) 'settlement cost' may be a more appropriate measure. Settlement cost accounts for proportionate return by incorporating settlement rates, the ratio of incoming to outgoing traffic, and carrier-specific market share in the cost calculation (Ford 1999).

${ }^{10} \partial \mathrm{Q}_{\mathrm{o}} / \partial \mathrm{Q}_{\mathrm{I}}>0$ is also consistent with the call externality having a positive effect on the demand for use. Taylor (1994) argues that for a large system, reverse-traffic is probably a better measure of community of interest than the number of reachable telephones. As such, a positive coefficient for reverse-traffic could reflect reversion, network and/or call externalities.

${ }^{11}$ For instance, re-originated services such as call-back and country-direct reverse the origin of calls to the US and allow consumers in foreign countries to take advantage of lower US collection rates.

${ }^{12}$ Mexico differs from the sample in that they do not have symmetrical outgoing and incoming settlement arrangements, and a "sum of local rates" scheme is employed by AT\&T in the collection rate pricing for US-Mexico traffic. AT\&T charge the domestic long-distance rate for the distance to the Mexican border, and then bill the amount the Mexican carrier charges from the border to the end destination. 
13 When discount collection rates vary more than listed collection rates, the listed collection rate change will understate actual rate changes and the estimated price elasticity of demand will overstate the true price elasticity.

${ }^{14}$ Ford and Jackson (1999) estimate short-run (long-run) price elasticities for US IMTS traffic of between -0.52 and $-0.14(-1.9$ and -0.33$)$. Acton and Vogelsang (1992) estimate a price elasticity of -0.36 for US telephone demand over the Atlantic from 1979 to 1986. Hackl and Westlund (1995) estimate price elasticities of approximately -1.0 for Germany from 1986 to 1991. Garin Munoz and Perez Amaral (1996) find a price elasticity of -0.77 for Spain during 1985 to 1989.

15 The ratio assumes constant marginal cost, and a constant market elasticity for relative prices (the ratio of monopoly to competitive prices) in the demand function (Scherer and Ross 1990, Ward 1995).

${ }^{16}$ For instance, consider a bilateral monopoly, whereby the US and foreign carrier face asymmetric cost and demand conditions, and settlement rate negotiations start from cost based settlement rates. Clearly, the low cost (high demand) US carrier will earn greater profits than its foreign counterpart, and as such, stands to lose more when an operating agreement is not concluded. By agreeing to a higher settlement rate, the US carrier shares some of its profits, in terms of settlement out-payments, with the high cost (low demand) foreign carrier (Cave and Donnelly 1996, Alleman 1998, Wright 1999, Madden and Savage). 
17 The FCC's (1997b) Benchmarks Order is an attempt to unilaterally lower settlement rates. The first phase of this Order go into effect for developed countries on 1 January 1999. 